\title{
GENDER DIFFERENCES OF PUPILS' KNOWLEDGE IN SELECTED FIELDS OF TECHNOLOGY
}

Pavel DOSTÁ $L^{*}$, Ostravská univerzita, Česká republika Svatopluk SLOVAK, Ostravská univerzita, Česká republika Radim ŠTĚPÁNEK, Ostravská univerzita, Česká republika Veronika ŠVRČINOVÁ, Ostravská univerzita, Česká republika

Přijato: 27. 5. 2020 / Akceptováno: 9. 7. 2020

Typ článku: Výzkumný článek

DOI: $10.5507 /$ jtie.2020.012

Abstract: The article presents the results of a research probe dealing with gender differences in the level of secondary school pupils' knowledge in the Czech Republic in the field of selected technically oriented topics. Based on data obtained using didactic tests of the cognitive level with the size of a research sample of almost a thousand male or female pupils, we can state that a significantly higher level of knowledge was identified in secondary school male pupils in the field of hand tools. A significantly higher level of knowledge of female pupils of the same age was identified in the field of textile production.

Key words: elementary school, gender, knowledge, research, technical education.

\section{GENDEROVÉ ROZDÍLY ZNALOSTÍ ŽÁKŮ VE VYBRANÝCH OBLASTECH TECHNIKY}

Abstrakt: Článek prezentuje výsledky výzkumné sondy zabývajici se genderovými rozdíly v úrovni znalostí žáků a žákyn̆ druhého stupně základnich škol v České republice v oblasti vybraných technicky orientovaných témat. Na základě dat ziskaných pomoci didaktických testů kognitivní úrovně s velikostí výzkumného vzorku téměř tisícovky žákủ či žákyn̆ můžeme konstatovat, že signifikantně vyšši úroveň znalostí byla u žákủ druhého stupně základnich škol identifikována v oblasti ručního náráadi. Signifikantně vy̌šsi úroveñ znalostí žákyn̆ stejného věku byla identifikována $v$ oblasti výroby textilu.

Klíčová slova: gender, technické vzdělávání, výzkum, základní škola, znalosti.

\footnotetext{
*Autor pro korespondenci: pavel.dostal@osu.cz
} 


\section{1 Úvod}

Současným trendem ve vzdělávání je odstraňování genderových segregací a rozvíjení individuálních předpokladů žáků a žákyň bez svazování očekáváními a pravidly vázanými na skutečnost, zda je člověk mužem či ženou. Tento trend má svůj odraz také v kurikulárních dokumentech. Stejně tak je tomu v Rámcovém vzdělávacím programu pro základní vzdělávání, který je v České republice kurikulárním dokumentem na státní úrovni. Ve vzdělávací oblasti Člověk a svět práce, která postihuje široké spektrum pracovních činností a technologií, je uvedeno: „vzdělávaci obsah je realizován na 1. i 2. stupni vzdělávání a je určen všem žákům (tedy chlapcưm i dívkám bez rozdílu) “ (MŠMT, 2017). Přesto sledujeme velké genderové rozdíly, například při volbě oboru střední nebo vysoké školy.

Gender je také někdy nazýván sociálním pohlavím. Na rozdíl od pojmu pohlaví, který je chápán výhradně v biologickém smyslu, označuje pojem gender kulturní charakteristiky a modely přiřazované mužskému nebo ženskému biologickému pohlaví a odkazuje na sociální rozdíly mezi ženami a muži. Tyto role se mění s časem a významně se liší podle kultury národa a dané historické etapy vývoje společnosti. Nejsou tedy vrozeným, daným rozdílem mezi muži a ženami, ale dočasným vývojovým stupněm sociálních vztahů (Český statistický úřad (dále jen ČSÚ), 2016). Členky a členové společnosti jsou socializováni tak, aby vykonávali své ženské a mužské role podle kulturně a dobově specifických požadavků (Valdrová, 2017). Gender je mocný společenský koncept, který zásadně strukturuje naše životy (Pavlík, 2007).

Vládní strategie pro rovnost žen a mužů v České republice na léta 2014-2020 si ve vzdělávacím systému všímá především dvou oblastí s vysokou mírou genderové nerovnosti. Tou první je vysoký podíl žen mezi vyučujícími v předškolním a školním vzdělávání (z celkového počtu vyučujících tvoří podíl žen v mateřských školách 99,7 \%, v základních školách 84 \%). Tou druhou je genderová nerovnost ve volbě studovaného oboru. Jako př́iklad jsou zde uvedeni vysokoškolští studenti technických oborů, mezi nimiž je 70 \% mužů (Úřad vlády České republiky, 2014).

Novější data jsou ilustrována na obr. č. 1. Mezi studujícími skupiny vysokoškolských studujících oborů Technika, výroba a stavebnictví je podíl žen 32,6 \%. Ještě výrazně menší podíl žen je ve skupině oborů Informační a komunikační technologie, pouze 16,5\% (Ondrušová, 2020).

Při bližším pohledu na skupinu oborů Technika, výroba a stavebnictví vidíme v jednotlivých oborových podskupinách velké rozdíly (obr. č. 2). V podskupině oborů Inženýrství a strojírenství byl v roce 2018 podíl žen pouze $21,2 \%$, naopak v podskupině oborů Výroba a zpracování byl v roce 2018 podíl žen 58,7 \% (ČSÚ, 2019).

Tato data však nejsou výrazným specifikem České republiky, podobná situace je např́iklad v USA (srov. NSF, 2019). Problém přetrvávajícího nízkého počtu žen $\mathrm{v}$ technických oborech a potřeba motivace mladých lidí, zejména dívek, ke studiu techniky je akcentován také Evropskou komisí (Dakers, 2009).

Přední ekonomové uvádí, že pro ekonomický růst a konkurenceschopnost je nezbytné, aby občané byli technicky (technologicky) gramotní bez genderových segregací (Reinkig, 2018; Ingerman, 2010; Weber, 2005; Bybee, 2003). Problému nízkého zapojení žen do technických (technologických) oborů, respektive do oborů STEM (Science, Technology, Engineering and Mathematics) je v odborné literatuře věnována velká pozornost. Jsou zdůrazňovány různé př́íčiny, učivo (Sanders, 1997), metody výuky (Shroyer, 1995), učební 
pomůcky (Zuga, 1999), genderové stereotypy (Shapiro, 2012; Gunderson, 2011; Witts, 1997), hračky, se kterými si děti hrají (Caleb, 2000; Sanders, 1997) a další.

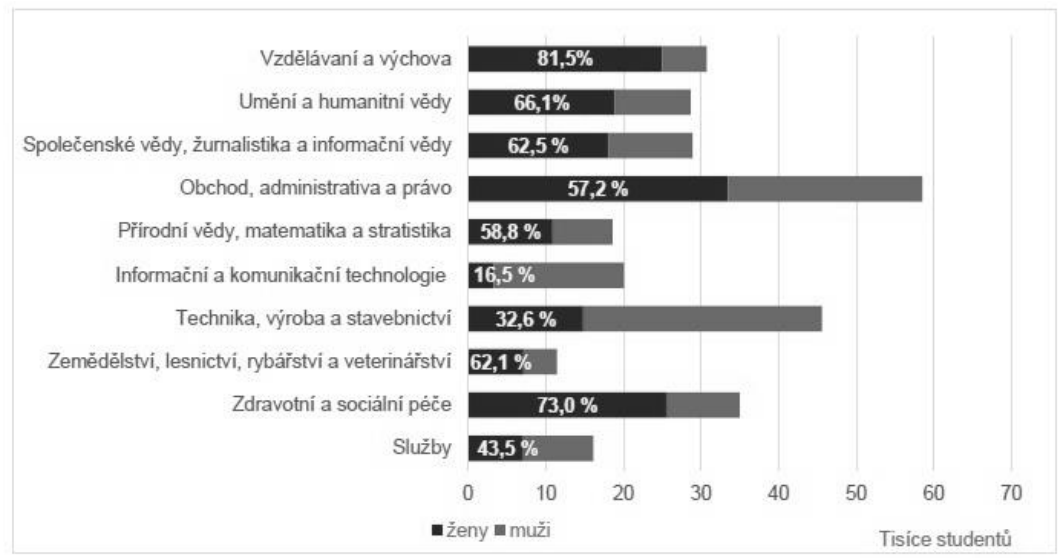

Obr. č. 1: Studenti vysokých škol podle skupin oborů v České republice v roce 2018

(Ondrušová, 2020).

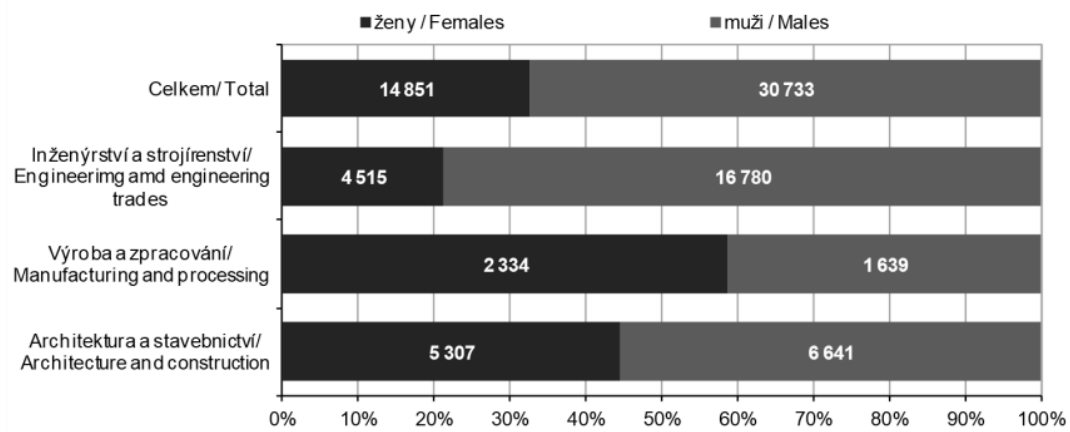

Obr. č. 2: Studenti vysokých škol skupiny oborů Technika, výroba a stavebnictví v České republice v roce 2018 (ČSÚ, 2019).

Není ambicí tohoto článku podrobně analyzovat příčiny nízkého zapojení žen do oborů STEM. Reinking a Martin (2018) je ve své studii přehledně rozdělily do tří skupin.

V první skupině jsou genderové stereotypy při socializaci dětí. Již od útlého věku jsou chlapci vychováváni, aby se přizpůsobili mužským rolím, děvčata jsou vychovávána, aby se přizpůsobila ženským rolím (SparkNotes Editors, 2006). Existující genderové stereotypy ve společnosti (ve škole) představují určitou generalizovanou charakteristiku dívek a chlapců, od nichž se očekávají určité schopnosti, charakterové vlastnosti i projevy chování (Částková, 2020). Postoje dívek jsou konfrontovány s názory okolí, včetně rodičů a učitelů, o nízkých schopnostech dívek ve STEM (Dasgupta, 2014; Gunderson, 2011, 
Smetáčková a Václavíková Helšusová, 2007). Při socializaci má obvykle zásadní význam rodina. Rodiče (a další lidé podílející se na výchově dětí) mají vliv na motivaci a výsledky v oblasti STEM (Partridge, 2008). Podrobněji ke genderové socializaci a vlivu rodiny na genderové rozdíly v disciplínách STEM např. (Eccles, 2014).

Ve druhé skupině jsou prríčiny spojené s rolí vrstevníků, respektive vrstevnických skupin. Vrstevníci mají důležitý vliv na chování a rozvoj dospívajících. Přijetí do vrstevnické skupiny patří k zásadním školním zkušenostem (You, 2011). Chlapci a dívky si vybírají další studium tak, aby bylo $\mathrm{v}$ souladu s genderovými normami a nevystavovali se tak riziku zesměšňování, popř́padě dokonce ztráty přátel. Jestliže se děti rozhodnou pro genderově netradiční volbu, mohou očekávat negativní reakce spolužáků/aček (Jarkovská, 2007).

Ve třetí skupině jsou stereotypy spojené s profesionály v oblastech STEM. Kromě toho, že v této oblasti pracuje více mužù, profese v oblasti STEM vykazují rysy sociální izolace. Sociální izolace jako profesní charakteristika není často dívkami vnímána jako kladná hodnota (Cheryan, 2015). Dalším zmiňovaným argumentem je nedostatek pozitivních ženských vzorů v oblastech STEM (Steinke, 2017).

Jak bylo uvedeno výše, tyto skutečnosti se promítají do pedagogických dokumentů. Rámcový vzdělávací program (MŠMT, 2017) je však stručným rámcovým materiálem a jeho naplnění vždy závisí na př́stupu konkrétních učitelů a učitelek (Václavíková Helšusová, 2007). Učitelé a učitelky často svým působením posilují genderové stereotypy a genderovou segregaci. Mnozí z nich si do školy přinášejí genderově stereotypní představy o tom, jaké by měli mít chlapci a dívky charakteristiky, jak by se měli chovat, čím by se měli zabývat (Valdrová, 2007). Ale, jak uvádí Smetáčková (2007), roli učitelů a učitelek bychom neměli přeceňovat.

„Může se zdát, že za odstraňováni všech typů stereotypů, včetně stereotypů genderových, jsou zodpovédni zejména samotné učitelky a učitelé, nebot' ti prímo pracuji $s$ dètmi, na které znevýhodněni plynoucí ze stereotypu dopadá nejtízivěji. Úlohu jednotlivých vyučujicich bychom však neměli přeceňovat, a to zejména proto, že to může svádèt k podhodnocení vlivu ostatnich aktérů školního života. Těmi jsou na jedné straně samotní žáci/kyně a predevším jejich rodiče, a na straně druhé vedeni škol, jejich zřizovatelé a dalši instituce v oblasti vzdělávání. " (Smetáčková, 2007, s. 44)

Formálně tedy podle Rámcového vzdělávacího programu pro základní vzdělávání (MŠMT, 2017) není na základních školách v České republice rozdíl mezi vzděláváním žáků a žákyň. Přestože existují i základní školy, kde se ve vzdělávací oblasti Člověk a svět práce vzdělávají žáci a žákyně odděleně se zaměřením na odlišné tematické celky, jedná se dnes pravděpodobně o menšinu. Všechny školy zapojené do našeho výzkumu formálně nedělají $\mathrm{v}$ této vzdělávací oblasti rozdíl mezi vzděláváním žáků a žákyň a vzdělávání je realizováno $\mathrm{v}$ pohlavně smíšených skupinách.

Pokud srovnáme situaci v České republice se zahraničím, zjistíme, že v některých zemích na základních školách samostatný vyučovací předmět zaměřený na techniku nebo práci nikdy neexistoval nebo byl zrušen (Lepistö, 2015). Tato témata jsou pak zahrnuta do šířeji koncipovaných předmětù (Syrjäläinen, 2014; Autio, 2013; Rasinen, 2009). V jiných státech takový samostatný vyučovací předmět existuje, např́ílad ve Velké Británii, na Slovensku, v Dánsku a ve Švédsku. Za př́ílad vývoje genderového př́stupu, který vykazuje mnohé paralely s vývojem v Československu a následně v České republice, nám může sloužit Finsko, jehož vzdělávací systém je často diskutován, mimo jiné v souvislosti 
$\mathrm{s}$ vysoce nadprůměrnými výsledky ve srovnávacích testech PISA, byt' v posledních letech zde došlo k poklesu (Blažek, 2019).

Ve Finsku existoval samostatný vyučovací předmět zaměřený na řemesla od roku 1886 (Marjanen, 2012). Před rokem 1970 byl předmět rozdělen zvlášt’ pro chlapce a zvlášt’ pro dívky $\mathrm{s}$ odlišným vzdělávacím obsahem. Navzdory změně $\mathrm{v}$ učebních osnovách $\mathrm{v}$ roce 1970 z genderového rozdělení na rozdělení na „ruční práce s textilem“ a „technické ruční práce“ si předmět zachoval svoji genderově dichotomickou povahu (Lepistö, 2015). Podobně jako v České republice na druhém stupni základních škol měly školy možnost rozhodovat o organizaci tohoto předmětu. Výuka, ,remesel“ mohla zahrnovat obě oblasti, nebo se mohla soustředit na jednu $\mathrm{z}$ nich. To vedlo $\mathrm{k}$ tomu, že v různých oblastech Finska, se tento předmět vyučoval odlišně, ale obvyklé bylo, že po čtvrtém ročníku si žáci a žákyně zvolili zaměření (Lepistö, 2011) a většina žákyň si zvolila zaměření na „práci s textilem“, většina žáků si zvolila zaměření na „technické práce“ Obvykle také „práci s textilem“ vyučovaly ženy a „technické práce“ vyučovali muži“ (Lindfors, 2012). Tato situace trvala v podstatě do roku 2014, kdy byl předmět redefinován jako „multimateriálni““ zahrnující řadu technologií s důrazem na genderovou rovnost (Lepistö, 2015). Situace je přehledně zobrazena na obr. č. 3 .

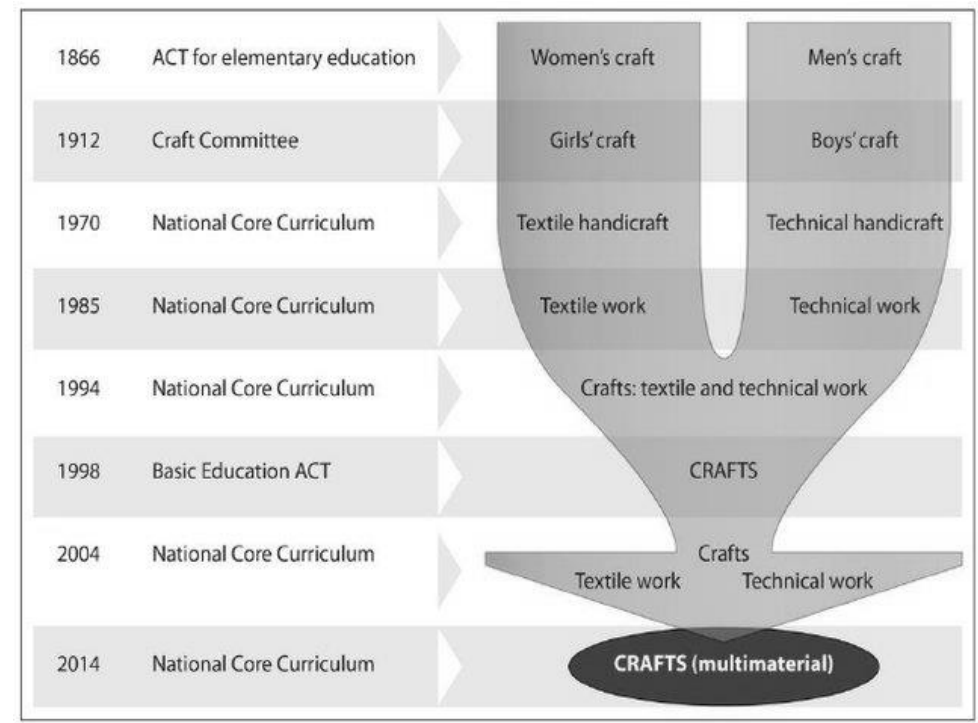

Obr. č. 3: Finsko - historický vývoj předmětu „řemesla“ (Lindfords, 2015).

Lewis (1999) ve své studii zformuloval v oblasti technického (technologického) vzdělávání osm základních okruhů s výzkumným potenciálem a některé s nimi související výzkumné otázky. Jedním z těchto okruhů je genderová problematika. V České republice byla technickému vzdělávání na základních školách $\mathrm{v}$ genderovém kontextu věnovaná 
v nedávné době pozornost například v pracích (Částková, 2020; Částková, 2016; Roučová, 2008; Honzíková, 2007).

Přestože je tedy genderové problematice $\mathrm{v}$ technickém vzdělávání pozornost věnována, jsou oblasti, které dosud stály poněkud stranou zájmu. Za jednu z nich považujeme výzkum genderových rozdílů v úrovni znalostí.

\section{Cíle výzkumu a použité metody}

Cílem výzkumné sondy bylo zjistit, zda jsou v současnosti rozdíly v úrovni znalostí mezi žáky a žákyněmi druhého stupně základních škol v České republice v oblasti vybraných technicky orientovaných témat.

Byla vybrána dvě témata - ruční náŕadí a výroba textilu. Na základě výsledků námi v minulosti realizovaných výzkumů a studia informačních zdrojů je možné předpokládat, že ve věkové kohortě druhého stupně základních škol budou vyšší úroveň znalostí v oblasti ručního nářadí vykazovat chlapci, naopak se dá předpokládat, že v oblasti výroby textilu budou vykazovat vyšší úroveň znalostí dívky.

Byly stanoveny dvě věcné hypotézy:

H1: Žáci druhého stupně základních škol prokáží vyšší úroveň znalostí v testu zaměřeném na ruční nářadí než žákyně těchto škol.

H2: Žákyně druhého stupně základních škol prokáží vyšší úroveň znalostí v testu zaměřeném na výrobu textilu než žáci těchto škol.

Hlavní metodou sběru dat byly didaktické testy. Pro každé téma byl použit samostatný objektivně skórovatelný test kognitivní úrovně. Tyto testy vlastní konstrukce jsme již v minulosti využili s výzkumným vzorkem více než 500 žákủ (či žákyň) druhého stupně základních škol, takže jsme znali některé jejich vlastnosti, jako např́klad indexy obtížnosti a koeficienty citlivosti testových úloh. $V$ testech byly použity položky otevřené se stručnou odpovědí (produkční a doplňovací), uzavřené s výběrem odpovědi a uzavřené přiřazovací. Z důvodu usnadnění testování na základních školách byly didaktické testy na školy distribuovány ve vytištěné podobě. Indikátorem úrovně znalostí byly počty bodů dosažených $\mathrm{v}$ těchto testech.

Výběrovým souborem byli všichni žáci a žákyně druhého stupně z deseti základních škol z Moravskoslezského a Zlínského kraje (přibližně 1000 žáků či žákyň).

Ke zjištění podmínek realizace vzdělávací oblasti Člověk a svět práce na jednotlivých školách byl využit elektronický dotazník, který vyplnili učitelé z těchto partnerských institucí. Výsledky vyplývající $z$ dotazníků byly následně doplněny o interview výzkumného pracovníka s těmito učiteli (př́padně řediteli). Pro zde prezentovanou výzkumnou sondu je především důležité, že všichni zástupci ze zapojených základních škol deklarovali, že na jejich škole není ve vzdělávací oblasti Člověk a svět práce rozdíl mezi vzděláváním chlapců a dívek.

K věcným hypotézám byly formulovány adekvátní statistické hypotézy, které byly testovány pomocí dvouvýběrového t-testu (s hladinou významnosti 0,05 ). Ke zpracování získaných dat a jejich statistickému vyhodnocení byl využit software Excel a PAST.

\section{Výsledky výzkumné sondy}

Ke statistickému testování byla věcná hypotéza $\mathrm{H} 1$ převedena na adekvátní statistické hypotézy $\mathrm{H} 1_{0}$ a $\mathrm{H} 1_{\mathrm{A}}$ (nulovou a alternativní): 
H10: Mezi průměrným počtem bodů získaným žáky a žákyněmi v testu zaměřeném na znalosti v oblasti ručního nářadí nebude statisticky významný rozdíl.

H1A: Žáci získají $\mathrm{v}$ testu zaměřeném na znalosti $\mathrm{v}$ oblasti ručního nářadí statisticky významně vyšší prưměrný počet bodů než žákyně.

Pomocí t-testu byly hodnoceny výsledky 453 testů vyplněných chlapci a 484 testů vyplněných dívkami. Získaná data jsou pro ilustraci zobrazena na obr. č. 4. Protože vypočtená p-hodnota $4,87 \cdot 10^{-32}$ je menší než zvolená hladina významnosti, můžeme zamítnout nulovou hypotézu.

$\mathrm{Na}$ základě provedené výzkumné sondy můžeme konstatovat, že u žáků druhého stupně základních škol byla indikována vy̌̌ší úroveň znalostí v oblasti ručního náradí než u žákyn̆.

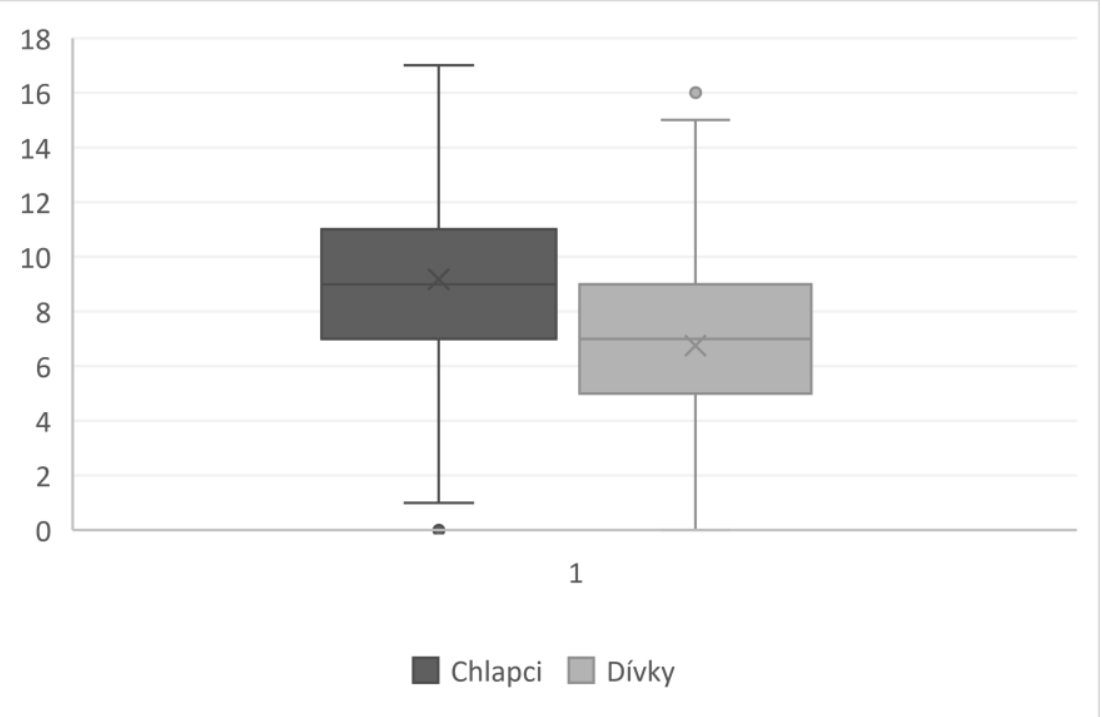

Obr. č. 4: Krabicový graf vizualizující počty bodů ziskaných v testu zaměřeném na ruční náŕadí chlapci a divkami.

Ke statistickému testování věcné hypotézy $\mathrm{H} 2$ byla tato prevedena na adekvátní statistické hypotézy $\mathrm{H} 20$ a $\mathrm{H} 2{ }_{\mathrm{A}}$ (nulovou a alternativní):

$\mathrm{H} 2_{0}$ : Mezi průměrným počtem bodů získaným žáky a žákyněmi $\mathrm{v}$ testu zaměřeném na znalosti v oblasti výroby textilu nebude statisticky významný rozdíl.

$\mathrm{H} 2_{\mathrm{A}}$ : Žákyně získají v testu zaměřeném na znalosti v oblasti výroby textilu statisticky významně vyšší průměrný počet bodů než žáci.

Pomocí t-testu byly hodnoceny výsledky 507 testů vyplněných chlapci a 480 testů vyplněných dívkami. Získaná data jsou pro ilustraci zobrazena na obr. č. 5. Protože vypočtená p-hodnota $3,59 \cdot 10^{-14}$ je menší než zvolená hladina významnosti, můžeme zamítnout nulovou hypotézu. 
Na základě provedené výzkumné sondy můžeme konstatovat, že u žákyň druhého stupně základních škol byla indikována vyšší úroveň znalostí v oblasti výroby textilu než u žáků.

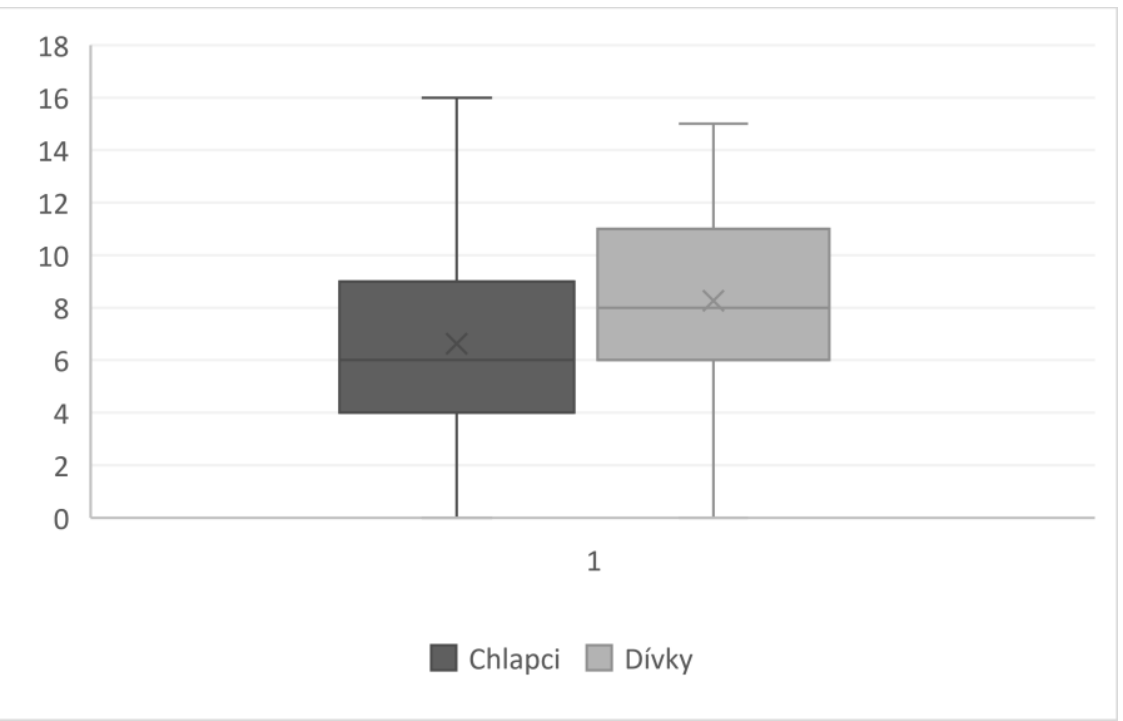

Obr. č. 5: Krabicový graf vizualizujicí počty bodi̊ ziskaných v testu zaměreném na výrobu textilu chlapci a divkami.

\section{Závěr}

Na základě provedeného výzkumu s výběrovým souborem blížíím se tisíci žáků či žákyň můžeme konstatovat, že žáci druhého stupně z deseti základních škol z Moravskoslezského a Zlínského kraje vykázali signifikantně vyšší úroveň znalostí v oblasti ručního nářadí. Žákyně stejného věku prokázaly signifikantně vyšší úroveň znalostí v oblasti výroby textilu.

Náš výzkum tedy potvrdil předpoklad genderových rozdílů znalostí v těchto tématech. Přestože ve výběrovém souboru byli žáci či žákyně pouze ze dvou krajů České republiky, můžeme se domnívat, že i v dalších krajích bude stav podobný.

Signifikantní rozdíly ve znalostech tedy existují, přestože kurikulární dokumenty v České republice ve vzdělávací oblasti Člověk a svět práce (a nejen v ní) nedělají rozdíl ve vzdělávání chlapců a dívek a totéž deklarují základní školy, na nichž výzkum proběhl.

Genderové nerovnosti jsou z hlediska společenských věd výjimečné svou trvanlivostí v čase (Pavlík, 2007). Skutečné odstraňování genderových stereotypů má zásadní význam pro hospodárský růst, prosperitu a konkurenceschopnost (Úřad vlády České republiky, 2014). Otázka, jak zatraktivnit techniku a technické vzdělání (nejen pro dívky), je zajisté důležitou otázkou také v souvislosti s probíhající kurikulární reformou v této oblasti. Nicméně tato problematika je součástí širokého kontextu a je pravděpodobné, že změny budou vyžadovat určitý čas. 
Prezentovaný výzkum probíhal v rámci projektu OP VVV Pregraduální vzdělávání v učitelských oborech na Pedagogické fakultě Ostravské univerzity (registrační číslo CZ.02.3.68/0.0/16_038/0006778).

\section{Literatura}

Autio, O. \& Soobik, M. (2013). A Comparative Study of Craft and Technology Education Curriculums and Students' Attitudes towards Craft and Technology in Finnish and Estonian Schools. Techne Seriess: Research in Sloyd Education and Craft Science A, 20(2), 17-33.

Blažek, R., Janotová, Z., Potužníková, E. \& Basl, J. (2019). Mezinárodní šetření PISA 2018: národní zpráva. Praha: Česká školní inspekce. ISBN 978-80-88087-24-3.

Bybee, R. W. (2003). Fulfilling a promise: Standards for technological literacy. The Technology Teacher, 62(6), 23-26.

Caleb, L. (2000). Design Technology: Learning How Girls Learn Best. Equity \& Excellence in Education, 33(1), 22-25. DOI: 10.1080/1066568000330105.

Částková, P., Dostál, J., Kropáč, J., \& Janu, M. (2019). Tvưrčí technické činnosti a tvořivost žáků základní školy z pohledu genderu. Journal of Technology and Information Education, 11(2), 18-29. DOI: 10.5507/jtie.2020.001.

Částková, P. \& Provázková Stolinská, D. (2016). Hodnocení a sebehodnocení žáků primární školy v technické výchově v genderovém kontextu. Trendy ve vzdělávání, 9(1), 28-36. DOI: 10.5507/tvv.2016.004.

ČSÚ. (2019). Zaostřeno na ženy a muže. Praha: ČSÚ. Dostupné z: https://www.czso.cz/csu/czso/zaostreno-na-zeny-a-muze-ffhk87f13g

ČSÚ. (2016). Gender: základni pojmy. Praha: ČSÚ. Dostupné z: https://www.czso.cz/csu/gender/gender_pojmy

Dakers, J. R., Dow, W., \& McNamee, L. (2009) De-constructing technology's masculinity. International Journal of Technology and Design Education, 19(4). DOI: 10.1007/s10798009-9099-3.

Dasgupta, N., \& Stout, J. G. (2014). Girls and Women in Science, Technology, Engineering, and Mathematics. Policy Insights from the Behavioral and Brain Sciences, 1(1), 21-29. DOI: 10.1177/2372732214549471.

Eccles, J. S. (2014). Gendered socialization of STEM interests in the family. 2nd Network Gender \& STEM Conference. Berlin: VHTO.

Gunderson, E. A., Ramirez, G., Levine, S. C., \& Beilock, S. L. (2011). New Directions for Research on the Role of Parents and Teachers in the Development of Gender-Related Math Attitudes: Response to Commentaries. Sex Roles, 66(3-4), 191-196. DOI: 10.1007/s11199-011-0100-8.

Honzíková, J. (2007). Gender - pojem ve školství známý i neznámý. In. XXV. International Colloquium on the Management of Educational Process: Aimed at Current Issues in Science, Education and Creative Thinking Development: sbornik na CD-ROMu. Brno: Univerzita obrany. ISBN 80-85960-92-3.

Ingerman, Å., \& Collier-Reed, B. (2010). Technological literacy reconsidered: a model for enactment. International Journal of Technology and Design Education, 21(2), 137-148. DOI: 10.1007/s10798-009-9108-6. 
Jarkovská., L. (2007). Ve škole je gender všude kolem nás. In Smetáčková, I. Přriručka pro genderově citlivé vedeni škol (s. 14-18). Praha: Otevřená společnost. ISBN 978-80-87110$01-0$.

Lepistö, J., \& Lindfors, E. (2015). From Gender-segregated Subjects to Multi-material Craft: Craft Student Teachers'Views on the Future of the Craft Subject. FormAkademiskForskningstidsskrift for Design Og Designdidaktikk, 8(3). DOI: 10.7577/formakademisk.1313.

Lepistö, J. (2011). Tyttöjen ja poikien käsityötaito: Totta vai tarua? In S. Laitinen \& Hilmola., A. (ed.). Taito-ja taideaineiden oppimistulokset-asiantuntijoiden arviointia. (pp. 175-193). Helsinki: Opetushallitus. ISBN 978-952-13-4732-0.

Lewis, T. (1999). Research in Technology Education-Some Areas of Need. Journal of Technology Education, 10(2). DOI: 10.21061/jte.v10i2.a.3.

Lindfors, E. (2015). Master degree as a promoter of craft, design and technology education in basic education. In Chatoney, M. (ed.). Plurality and complimentary of approaches in design and technology education, PATT29. (pp. 250-255). Marseille: Universataires de Provences. ISBN 978-2-85399-994-6.

Lindfors, E. (2012). Käsityön ainedidaktinen tutkimus ja haasteet 2000-luvulla. In A. Kallioniemi \& Virta, A. (ed.). Ainedidaktiikka tutkimuskohteena ja tiedonalana (pp. 360-388). Suomen kasvatustieteen seura. ISBN 97895254016222.

Marjanen, P. (2012). Koulukäsityö vuosina, 1866-2003: Kodin hyvinvointiin kasvattavista tavoitteista kohti elämänhallinnan taitoja. Turku: University of Turku. ISBN 978-951295142-0

MŠMT. (2017). Rámcový vzdělávací program pro základní vzdělávání. Praha: MŠMT. Dostupné z: http://www.msmt.cz/file/43792/

NSF. (2019). Women, minorities, and Persons with Disabilities in Science and Engineering. Alexandria: NSF Dostupné z: https://ncses.nsf.gov/pubs/nsf19304/

Ondrušová, A. (2020). Studenti a absolventi vysokých a vyššich odborných škol v $\check{C} R$ 2018. Praha: ČSÚ. Dostupné z: https://www.czso.cz/csu/czso/studenti-a-absolventivysokych-a-vyssich-odbornych-skol-v-cr-2018

Pavlík, P. (2007). Ženy a muži v genderové perspektivě: gender přináší nový pohled. In Smetáčková, I. Přiručka pro genderově citlivé vedeni škol (s. 7-13). Praha: Otevřená společnost. ISBN 978-80-87110-01-0.

Rasinen, A., Virtanen, S., Endepohls-Ulpe, M. et al. (2009). Technology education for children in primary schools in Finland and Germany: different school systems, similar problems and how to overcome them. International Journal of Technology and Design Education, 19(4), 367-379. DOI: 10.1007/s10798-009-9097-5.

Reinking, A., \& Martin, B. (2018). The Gender Gap in STEM Fields: Theories, Movements, and Ideas to Engage Girls in STEM. Journal of New Approaches in Educational Research, 7(2), 148-153. DOI: 10.7821/naer.2018.7.271.

Roučková, E. (2008). Problematika genderu v technickém vzdělávání. Trendy ve vzdělávání, 1(1), 214-217.

Sanders, J. S., Koch, J., \& Urso, J. (1997). Gender equity right from the start: instructional activities for teacher educators in mathematics, science, and technology. Mahwah: L. Erlbaum Associates. 
Shapiro, J. R., \& Williams, A. M. (2012). The Role of Stereotype Threats in Undermining Girls' and Women's Performance and Interest in STEM Fields. Sex Roles, 66(3-4), 175183. DOI: $10.1007 / \mathrm{s} 11199-011-0051-0$.

Shroyer, M., Backe, K., \& Powell, J. (1995). Developing a science curriculum that addresses the learning preferences of male and female middle level students. In D. Baker, \& K. Scantlebury, (Eds). Science "Co Education”: Viewpoints for Gender, Race and Ethnic Perspectives. National Association for Research in Science Teaching.

SparkNotes Editors. (2006). SparkNote on Socialization. Dostupné z: http://www.sparknotes.com/sociology/socialization/

Smetáčková, I. (2007). Genderově rovná škola, genderově citlivá výuka. In Smetáčková, I. Přiručka pro genderově citlivé vedení škol (s. 44-49). Praha: Otevřená společnost. ISBN 978-80-87110-01-0.

Smetáčková, I. \& Václavíková Helšusová, V. (2007). Dívky a chlapci: rozdílné výsledky, rozdílný styl učení, rozdílné představy? In Smetáčková, I. Přiručka pro genderově citlivé vedeni škol (s. 14-18). Praha: Otevřená společnost. ISBN 978-80-87110-01-0.

Steinke, J. (2017). Adolescent Girls' STEM Identity Formation and Media Images of STEM Professionals: Considering the Influence of Contextual Cues. Frontiers in Psychology, 8. DOI: 10.3389/fpsyg.2017.00716.

Syrjäläinen, E. \& Seitamaa-Hakkarainen, P. (2014). The quality of design in 9th grade pupils' design-and-make assignments in craft education. Design and Technology Education: An International Journal, 19(2), 30-39.

Úřad vlády České republiky. (2014). Vládní strategie pro rovnost žen a mužů v České republice na léta 2014-2020. Dostupné z: https://www.vlada.cz/assets/ppov/rovneprilezitosti-zen-a-muzu/Projekt_Optimalizace/Strategie-pro-rovnost-zen-a-muzu-v-CRna-leta-2014-2020.pdf

Václavíková Helšusová, L. (2007). Co se učí dívky a chlapci? In Smetáčková, I. Přiručka pro genderově citlivé vedení škol (s. 19-22). Praha: Otevřená společnost. ISBN 978-8087110-01-0.

Valdrová, J. (2017). Gender. In Karlík, P., Nekula, M., \& Pleskalová, J. Nový encyklopedický slovník češtiny. Dost. z: https://www.czechency.org/slovnik/GENDER Valdrová, J. (2007). Komunikace mezi vyučujícími a studujícími. In Smetáčková, I. Přiručka pro genderově citlivé vedení škol (s. 23-28). Praha: Otevřená společnost. ISBN 978-80-87110-01-0.

Weber, K., \& Custer, R. (2005). Gender-based Preferences toward Technology Education Content, Activities, and Instructional Methods. Journal of Technology Education, 16(2), 55-71. DOI: 10.21061/jte.v16i2.a.4.

Witts, S. D. (1997). Parental influence on children's socialization to gender roles. Adolescence, 32(126), 253-259.

You, S. (2011). Peer influence and adolescents' school engagement. Procedia - Social and Behavioral Sciences, 29, 829-835. DOI: 10.1016/j.sbspro.2011.11.311.

Zuga, K. F. (1999). Addressing Womens Ways of Knowing to Improve the Technology Education Environment for All Students. Journal of Technology Education, 10(2). DOI: 10.21061/jte.v10i2.a.4. 